CZU 349.6(478)

DOI: https://doi.org/10.52388/2345-1971.2021.1.11

\title{
LEGAL REGIME FOR WASTE MANAGEMENT IN THE REPUBLIC OF MOLDOVA
}

\author{
Andrian CRETU \\ Doctor of Law, University of European Political and Economic Studies „Constantin Stere”, \\ Chisinau, Republic of Moldova \\ e-mail:andrian.cretu@gmail.com \\ https://orcid.org/0000-0002-8144-5233
}

This article contains a study in the field of interaction and dependence of constitutional guarantees of Human Rights in the Republic of Moldova on power, economy and capital. The author analyzes the set of meanings and forms of this democracy, the measure, level and values of citizens who make up a collective or a lot of people, from the point of view of the means and methods of applying democratic principles through the prism of citizens ' involvement in the leadership of the state. The interaction and direct dependence of the implementation of constitutional norms by the political will, the level of the economy, including the interest and purpose of the dictatorship of capital, is subject to analysis. The real problem of Western-type democracy with regard to the expectations of citizens is also analyzed. The article also provides an assessment of democratic values in their current form and content. The most common and independent opinions, ideas and doctrines are analyzed. Similarly, an analysis is carried out from the general ideological point of view and the achievement of objective effects, including the subsequent occurrence of certain consequences. A comparative analysis is made on the opinions of other famous specialists in this field.

Keywords: waste, recycling, natural resources, extended responsibility, environmental authorities.

\section{REGIMUL JURIDIC AL GESTIONĂRII DEŞEURILOR ÎN REPUBLICA MOLDOVA}

Creșterea demografică, mai ales cea înregistrată în ultimele decenii, nu avea cum să nu aducă cu sine și un șir de probleme, în special, cele legate de mediu. Or, odată cu aceasta crește volumul consumului, iar pe cale de consecință și a deșeurilor de pe urma consumului de produse și servicii. Mai mult, resursele epuizabile devin cele mai vulnerabile, imposibil de compensat chiar și pe calea reciclării deșeurilor rezultate din utilizarea produselor, iar acestea, la rândul lor, din utilizarea materiei prime care, în linii mari, constituie resurse naturale epuizabile. Considerentele arătate, în mod normal, au determinat legiuitorii statelor dezvoltate să recurgă la măsuri mult mai precise, directe și eficiente pe segmentul regimului juridic al gestionării deșeurilor de orice fel. Așa s-a făcut, ca în ultimul deceniu, legislația europeană să cunoască noi mecanisme şi concepte ce au drept obiectiv reducerea deșeurilor și gestionarea eficientă a celor existente. Unul din acestea ar fi de menționat sistemul economii circulare care emană în diverse alte mecanisme strategice ajutătoare cum ar fi: ecodesignul; ecomarketingul; responsabilitatea extinsă a producătorului; urmărirea ciclului de viață a produsului; achizițiile ecologice; raportarea informației despre măsurile aplicate în vederea reducerii impactului negativ asupra mediului și altele, unele din ele, recent, fiind preluate și implementate și în Republica Moldova - țară cu mari aspirații orientate în direcția integrării europene.

Cuvinte-cheie: deșeuri, reciclare, resurse naturale, responsabilitate extinsă, autorități de mediu.

\section{RÉGIME JURIDIQUE DE LA GESTION DES DÉCHETS EN RÉPUBLIQUE DE MOLDOVA}

Cet article contient une étude dans le domaine de l'interaction et de la dépendance des garanties constitutionnelles des Droits de l'Homme en République de Moldova vis-à-vis du pouvoir, de l'économie et du capital. L'auteur analyse l'ensemble des significations et des formes de cette démocratie, la mesure, le niveau et les valeurs des citoyens qui composent un collectif ou beaucoup de personnes, du point 
de vue des moyens et des méthodes d'application des principes démocratiques à travers le prisme de l'implication des citoyens dans la direction de l'État. L'interaction et la dépendance directe de la mise en ouvre des normes constitutionnelles par la volonté politique, le niveau de l'économie, y compris l'intérêt et le but de la dictature du capital, sont sujets à analyse. Le véritable problème de la démocratie de type occidental en ce qui concerne les attentes des citoyens est également analysé. L'article fournit également une évaluation des valeurs démocratiques dans leur forme et leur contenu actuels. Les opinions, idées et doctrines les plus courantes et les plus indépendantes sont analysées. De même, une analyse est effectuée du point de vue idéologique général et de la réalisation d'effets objectifs, y compris l'apparition ultérieure de certaines conséquences. Une analyse comparative est faite sur les opinions d'autres spécialistes célèbres dans ce domaine.

Mots-clés: déchets, recyclage, ressources naturelles, responsabilité élargie, autorités environnementales.

\section{ПРАВОВОЙ РЕЖИМ МЕНЕДЖМЕНТА ОТХОДОВ В РЕСПУБЛИКЕ МОЛДОВА}

Демографический рост, особенно в последние десятилетия, не мог не повлечь за собой ряд проблем, особенно связанных с окружсающей средой. В то же время, увеличивается объем потребления, следовательно, и отходы от потребления продуктов и услуг. Более того, истощаемые ресурсы становятся наиболее уязвимыми, и их невозможно компенсировать даже за счет переработки отходов, возникающих в результате использования продуктов, а это, в свою очередь, из-за использования сырья, которое, как правило, является истощаемым природным ресурсом. Вышеупомянутые соображения обычно побуждали законодателей развитых стран прибегать к гораздо более точным, прямым и эффективным мерам в сегменте правового режима обращения с отходами любого рода. Таким образом, в последнее десятилетие европейское законодательство узнало о новых механизмах и концепциях, направленных на сокращение отходов и эффективное управление существующими отходами. Один из них следует упомянуть - речь идет о системе ииркулярной экономики, которая проявляется в различных других полезных стратегических механизмах, таких как: экодизайн; экомаркетинг; расширенная ответственность производителя; отслеживание жизненного ичикла продукта; зеленые закупки; обнародование информации о мерах, принятых для снижения негативного воздействия на окружаюшую среду, и других, некоторые из которых недавно были приняты и реализованы в Республике Молдова - стране с высокими стремлениями к европейской интеграции.

Ключевые слова: отходы, переработка, природные ресурсы, расширенная ответственность, природоохранные органы.

\section{Introducere}

Dezvoltarea industrială şi tehnologică din ultimii ani a condus la o creștere fără precedent a nivelului de producere, prelucrare şi distribuție a mărfurilor însă, din păcate, nu a înregistrat progrese şi în direcția dezvoltării tehnicilor de gestionare a deșeurilor rezultate. Mai mult, adoptarea treptată a unui cadru normativ strict cu privire la gestionarea deșeurilor a determinat apariția unei piețe de deșeuri de proporții, în jurul căreia coexistă, într-un fel mai mult sau mai puţin deghizată, o serie de interese economice.

Problema gestionării deșeurilor în Republica Moldova rămâne a fi o problemă destul de dificilă şi nerezolvată ,atât din punct de vedere organizatoric, cât şi legislativ". Cu toate că domeniul protecției mediului este reglementat de un şir de acte legislative şi normative, aspectul legal al gestionării deșeurilor lasă mult de dorit, fiind necesară atât restructurarea cadrului legal şi instituțional, cât şi crearea unui sistem integru de reglementare tehnică şi ecologică în domeniile de colectare selectivă pentru reciclarea, valorificarea, eliminarea şi depozitarea deșeurilor. Or, potrivit unor date, generarea deșeurilor fluctuează anual, iar cantitatea deșeurilor utilizate şi înhumate este în creștere.

Actualmente, cea mai utilizată metodă de tratare a deșeurilor menajere este depozitarea 
pe sol, care reprezintă frecvent o sursă importantă de poluare a solului şi apelor subterane.

În contextul dat, salubritatea localităţilor şi managementul deșeurilor urbane constituie un obiectiv important al structurilor guvernamentale şi locale. Anual, prin intermediul serviciilor de salubrizare din localităţile urbane se transportă la depozite de DMS circa 1144-2210 $\mathrm{mii} \mathrm{m}^{3}$ de deșeuri. Soluția cea mai bună în acest caz ar fi prelucrarea deșeurilor fie de unii agenții economici, fie de unele întreprinderi de stat şi municipale, fapt care nu se realizează. Din cauza aceasta, nemulțumirile populației sunt în creștere în privinţa disconfortului creat prin depozitarea acestora la sol în apropierea localităților.

$\mathrm{Cu}$ toate că în Republica Moldova funcționează câteva întreprinderi de prelucrare a deșeurilor, informația privind volumele de deșeuri reciclate nu este supusă evidenței statistice.

În anul 2008 a fost generată o cantitate totală de 2841,7 mii tone deșeuri provenite din activitatea întreprinderilor. Cea mai mare parte a acestora, circa 1570 mii de tone, este reprezentată de deșeuri aferente industriei alimentare şi a băuturilor, alte 540 mii tone sunt deșeuri de la întreprinderile de extracție, 249 mii tone provin de la creștere.

Din cantitatea de deșeuri de producție, doar $30 \%$ au fost utilizate, $50 \%$ sunt eliminate prin depozitare la gunoiști, iar $20 \%$ rămân în stoc pe teritoriul întreprinderilor.

În consecință, gestionarea necorespunzătoare a deșeurilor pe parcursul ultimilor ani afectează comunitățile locale, amenință mediul şi contribuie la emisiile globale de gaze cu efect de seră [8, p.182], destul de periculoase și agresiv amenințătoare aspra sănătății populației din zonă.

La capitolul reglementărilor în domeniul gestionării deșeurilor, Republica Moldova întâlnește anumite dificultăţi de aplicare a lor, deși legislația este adaptată parțial la cadrul legislativ european, nu există încă suficiențe resurse și subiecți calificați în gestionarea co- rectă a deșeurilor, și în general, nu există un mecanism clar cu privire la aceasta. Or, deși noua lege privind deșeurile [3], prevede mecanismul responsabilității extinse a producătorului nu prevede și o responsabilitate a consumatorului - cel mai mare generator de deșeuri menajere. De asemenea, mecanismul responsabilității extinse a producătorului, deși cunoaște reglementare din anul 2016, actualmente (2021) încă nu este funcțional.

Scopul articolului este de a sensibiliza producătorul, consumatorul, comerciantul și toți ceilalți subiecți generatori de deșeuri de orice fel, despre pericolul deșeurilor asupra mediului și, în consecință, asupra vieții și sănătății omului. Mai mult, studiul urmărește scopul identificării și sugerării legiuitorului unor soluții de îmbunătăţire a cadrului normativ ajutător Legii nr. 209/2016 care ar constitui suport pentru implementarea deplină a mecanismului responsabilității extinse a producătorului, în calitate de mecanism economico-financiar de protecție a mediului. Mai mult, lucrarea de față intenționează a oferi material, sugestii și tălmăciri distincte cadrului juridic doctrinar, atât de necesar generațiilor de cercetători preocupaţi de protecția mediului.

Metode și materialele aplicate. La elaborarea prezentei lucrări am recurs la utilizarea unui spectru larg de metode de cercetare științifică, dintre care enumerăm: metoda istorică, metoda analizei, metoda sintezei, metoda deducției, metoda sistemică, metoda empirică, metoda experimentului, metoda interpretativă. De asemenea, la baza lucrării avem și materialele scrise de noi cu ocazia elaborării altor lucrări, materiale ale autorilor străini și autohtoni consacrați domeniului protecției mediului, dintre care menționăm pe I. Trofimov, G. Ardelean, P. Zamfir, R. Iordanov. A. Rotaru, V. Așevschi, A. Capcelea, Gh. Duca și alţi autori remarcaţi.

\section{Rezultate obținute și discuții}

În contextul creșterii volumului şi diversităţii deșeurilor generate, gestionarea 
şi reciclarea lor devine o prioritate locală, națională şi internațională $[5$, p.11]. Aceasta se impune din anumite considerente şi factori ce au condus la gestionarea proastă a deșeurilor, atât în zonele urbane, cât şi în cele rurale.

Astfel, urbanizarea influențează şi ea generarea de deșeuri, iar locuitorii din zonele urbane produc mult mai multe deșeuri decât cei din zona rurală. În multe așezări rurale serviciul de salubrizare funcționează insuficient, iar în unele nici nu există un astfel de serviciu, prin urmare o cantitate de deșeuri rămân în localități.

Totodată, crearea serviciilor de salubrizare pentru localitățile rurale va cere cheltuieli şi timp, însă, problema deșeurilor nu poate fi neglijată.

O perspectivă a soluționării acestei probleme, ar fi organizarea evacuării şi depozitării finale al reziduurilor, sau chiar trecerea la metoda depozitării controlate, care se realizează în spații adecvate cu acțiuni de prevenire a poluării mediului, condiții favorabile fermentării, fără înmulțirea insectelor şi rozătoarelor în conformitate cu cerințele sanitare.

\section{Reglementări privind regimul juridic de gestionare a deșeurilor de producție şi menajere}

Urbanizarea accelerată a determinat o creștere impresionantă a cantităţii de deșeuri, iar dezvoltarea științelor și economiei a generat și o serie de probleme legate de marea diversitate a materialelor noi utilizate în diferite domenii. Beneficiile tehnologiilor moderne - incontestabile, pe de o parte - sunt „grevate" de procesele de fabricație care implică aspecte deosebite aferente gestionării ecologice a deșeurilor rezultate ca urmare a realizării și utilizării tipurilor noi de ambalaje. Una dintre marile dificultăţi asociate sistemelor moderne de împachetare și conservare a produselor este asociată acestor noi tipuri de materiale (deci noi tipuri de deșeuri posibil de reciclat): masele plastice [6, p.88], spre exemplu.

Pentru a face față acestor ,provocări”, specialiștii și-au concentrat preocupările în direcția stabilirii unui sistem global de gestionare a deșeurilor, apărând în acest fel un nou domeniu de interes - managementul deșeurilor solide [6].

Potrivit reglementărilor mai vechi în domeniu [4], deșeurile constituie substanțe, materiale, obiecte, resturi de materii prime provenite din activități economice, menajere şi de consum, care şi-au pierdut, integral sau parțial, valoarea inițială de întrebuințare, dintre care unele sunt reutilizabile după prelucrare. Legea actuală, în planul definirii noțiunii de deșeu, devine mai lacunară, menționând că este deșeu orice substanță sau obiect pe care deținătorul îl aruncă sau are intenția ori obligația să îl arunce. Vedem deci, că deșeuri se consideră nu doar substanțele materiale aruncate, ci și cele ce urmează a fi aruncate ori trebuie aruncate (depozitate) în mod obligatoriu.

În sensul noii legi, gestionarea deșeurilor înseamnă - colectarea, transportul, valorificarea şi eliminarea deșeurilor, inclusiv supravegherea acestor operațiuni şi întreținerea ulterioară a amplasamentelor de eliminare, inclusiv acțiunile întreprinse de un comerciant sau un broker.

În aceiași direcție, prin regim juridic de gestionare a deșeurilor se are în vedere elaborarea şi punerea în aplicare a normelor ce stau la baza oricărei activități legate de formarea, tratarea, ambalarea, depozitarea, transportarea, acumularea, neutralizarea, prelucrarea, utilizarea, înhumarea sau distrugerea deșeurilor.

Acestea fiind definite, mai trebuie de specificat faptul că funcționalitatea eficientă a cadrului juridic de reglementare, potrivit unor tactici şi norme, sporește în contextul în care acesta se bazează pe o divizare judicioasă a tuturor compartimentelor care îl alcătuiesc.

În această ordine de idei, legiuitorul a reglementat regimul juridic de gestionare a 
deșeurilor ținând cont de următoarele compartimente:

$>$ competența autorităților administrației publice centrale și locale;

cerințe generale privind gestionarea deșeurilor;

autorizarea, controlul, evidenţa şi sistemul informațional în domeniul activităţilor de gestionare a deșeurilor;

$>$ obligații în domeniul gestionării deșeurilor;

cerințe de gestionare a anumitor categorii de deșeuri importul şi exportul deșeurilor;

$>$ răspunderea pentru încălcarea legislației privind deșeurile.

\section{Competența autorităților administrației publice centrale și locale}

În scopul asigurării eficienței activităților în domeniul gestionării deșeurilor, prin legislația în vigoare se împuternicesc o serie de organe cu competență atât de specialitate, cât şi generale.

Totuși, ținând cont de complexitatea domeniului respectiv, a fost necesară şi o delimitare strictă a competențelor fiecărui subiect învestit cu atribuții în asigurarea securității utilizării produselor şi deșeurilor de producție şi menajere.

Astfel, întru realizarea atribuțiilor sale $G u$ vernul Republicii Moldova deține următoarele competențe distincte:

a) realizează obiectivele şi stabilește direcțiile prioritare în domeniul gestionării deșeurilor;

b) aprobă Strategia națională de gestionare a deșeurilor şi Programul național pentru gestionarea deșeurilor;

c) aprobă actele normative în domeniul gestionării deșeurilor pentru asigurarea implementării prezentei legi, inclusiv metodologia de calculare a tarifelor în acest domeniu;

d) determină modalitatea de gestionare a unor categorii de deșeuri, inclusiv a celor periculoase, în conformitate cu prevederile prezentei legi şi ale legislaţiei internaţionale; e) în cazul în care autoritățile administrației publice locale nu-şi dau acordul în termen de 3 luni din momentul sesizării acestora, ia deciziile definitive pentru amplasarea obiectelor regionale de importanță națională privind valorificarea, tratarea, reciclarea, eliminarea, depozitarea sau înhumarea deșeurilor, cu condiția respectării cerințelor de mediu, conform Legii exproprierii pentru cauză de utilitate publică nr. 488-XIV din 8 iulie 1999, şi a altor cerințe de ordin social.

Autoritatea centrală, abilitată cu gestiunea resurselor naturale şi cu protecția mediului înconjurător - Ministerul Agriculturii, Dezvoltării Regionale și Mediului, are următoarele atributii:

a) elaborează, pregătește spre aprobare şi coordonează realizarea documentelor de politici prevăzute la art. 8 lit. b) şi implementarea tratatelor internaționale la care Republica Moldova este parte;

b) inițiază şi asigură elaborarea, promovarea spre aprobare şi coordonarea realizării actelor legislative şi actelor normative ale Guvernului în domeniul gestionării deșeurilor;

c) dirijează metodologic organizarea evaluării impactului asupra mediului evaluării strategice de mediu și a expertizei ecologice de stat;

d) asigură monitorizarea, prin intermediul autorităților administrative subordonate, a impactului asupra factorilor de mediu cauzat de deșeuri şi deduce indicatorii de gestionare a deșeurilor;

e) constituie, prin intermediul autorităţii administrative din subordine, punctul de legătură pentru comunicarea şi cooperarea cu Agenția Europeană de Mediu în ceea ce privește legislația privind deșeurile şi indicatorii de gestionare a acestora;

f) constituie autoritate competentă, punct oficial de contact şi punct focal pentru tratatele internaţionale de mediu cu privire la gestionarea deșeurilor la care Republica Moldova este parte; 
g) asigură coordonarea procesului de stabilire a instrumentelor economice pentru reducerea efectelor negative cauzate de deșeuri pentru mediu, inclusiv a procesului de elaborare, operare şi emitere a deciziei de eliberare a garanției financiare stabilite pentru acoperirea costurilor de finanțare a operațiunilor de colectare, tratare, valorificare şi eliminare a deșeurilor de produse supuse unui regim de răspundere extinsă a producătorului;

h) examinează şi aprobă planurile anuale de acțiuni ale autorităților administrative subordonate în ceea ce privește supravegherea şi controlul gestionării deșeurilor, de asemenea monitorizează implementarea acestora;

i) prezintă şi asigură Guvernul cu informații privind implementarea documentelor de politici menţionate la lit. a) și cu informații privind gestionarea deșeurilor şi starea mediului în raport cu gestionarea deșeurilor;

j) contribuie la colectarea şi diseminarea informației privind generarea deșeurilor şi măsurile de gestionare a acestora, inclusiv în context transfrontalier, şi asigură accesul publicului la informație conform prevederilor art. 38;

k) organizează, împreună cu alte autorităţi publice şi cu organizațiile neguvernamentale, programe de instruire şi educare a populaţiei în domeniul gestionării deșeurilor;

1) asigură colaborarea administrativă şi schimbul de informații cu alte state și organizații internaționale în domeniul gestionării deșeurilor, precum şi raportarea în cadrul tratatelor internaționale de mediu cu privire la gestionarea deșeurilor la care Republica Moldova este parte conform procedurilor de raportare şi comunicații stabilite în cadrul acestora;

m) constituie posesorul Sistemului informațional automatizat „Managementul deșeurilor" (denumit în continuare - SIAMD), menţionat la art. 33 şi asigură condiţiile juridice, organizatorice şi financiare pentru crearea acestuia.
Deciziile luate, în limitele competenței sale, de autoritatea centrală abilitată cu gestiunea resurselor naturale şi cu protecția mediului înconjurător în domeniul gestionării deșeurilor sunt executorii pentru toți agenții economici şi pot fi atacate în instanța de contencios administrativ competentă.

$\mathrm{Cu}$ competențe în domeniul gestionării deșeurilor sunt învestite mai multe autorități din subordinea autorităţii centrale în domeniul protecției mediului, cum ar fi:

$\checkmark$ Agenția de Mediu, cu următoarele atribuții:

a) participă la promovarea politicii de stat în domeniul gestionării deșeurilor;

b) asigură implementarea sistemului integrat de gestionare a deșeurilor

c) participă la elaborarea şi implementarea strategiilor de gestionare a deșeurilor şi a programelor speciale de prevenire şi pronosticare a formării deșeurilor, precum şi de combatere şi lichidare a focarelor de stocuri de deșeuri periculoase;

d) participă la elaborarea şi avizarea proiectelor de acte normative privind gestionarea deșeurilor;

e) participă la implementarea tratatelor şi acordurilor internaționale ce țin de gestionarea deșeurilor şi transportarea peste frontieră a acestora;

f) colaborează, în limitele competenței, pe probleme de gestionare a deșeurilor, cu autoritățile administraţiei publice centrale şi locale, cu Academia de Științe a Moldovei cu instituții de cercetări științifice, cu instituțiile de învățământ şi asociaţiile obștești de profil, $\mathrm{cu}$ alte persoane juridice de drept public sau privat, precum şi cu persoane fizice;

g) organizează, în limitele competenței, seminare, conferințe la nivel național şi regional, instruirea cadrelor, agenţilor economici şi informarea publicului pe probleme ce țin de gestionarea deșeurilor;

h) examinează documentaţia privind evaluarea impactului asupra mediului şi emite acor- 
dul de mediu pentru proiecte publice şi private, inclusiv pentru activităţile planificate ce ţin de gestionarea deșeurilor;

i) efectuează expertiza ecologică de stat a proiectelor de documente de politici, a actelor normative în domeniul gestionării deșeurilor şi documentaţiei de proiect şi planificare pentru construcția sau reconstrucția întreprinderilor şi altor obiecte generatoare de deșeuri, precum şi pentru obiectele ce țin de infrastructura de gestionare a deșeurilor;

j) asigură eliberarea, suspendarea, prelungirea sau retragerea, conform art. 25, a autorizaţiei de mediu pentru gestionarea deșeurilor, inclusiv pentru dotarea şi disponibilitatea permanentă a instalațiilor portuare;

k) eliberează documentele de notificare la transportarea peste frontieră a deșeurilor, conform actelor normative aprobate de Guvern;

1) asigură stabilirea țintelor de colectare separată şi reciclare pentru deșeurile de produse supuse reglementărilor de responsabilitate extinsă a producătorului, conform prezentei legi şi actelor normative aprobate de Guvern;

m) este deținătorul SIA MD şi asigură tinerea acestuia.

$\checkmark$ Inspectoratul pentru Protecția Mediului, cu următoarele atribuții:

a) exercită controlul și supravegherea de stat a gestionării deșeurilor, inclusiv a deșeurilor de produse supuse reglementărilor de responsabilitate extinsă a producătorului, exercită controlul în domeniile de activitate economică asupra respectării prevederilor prezentei legi și ale actelor normative de către instituţii, organizații, agenții economici, indiferent de tipul de proprietate şi forma juridică de organizare, şi de către persoanele fizice, inclusiv străine;

b) exercită controlul de stat privind respectarea de către instituții, organizații şi agenții economici a limitelor de depozitare a deșeurilor, a țintelor de colectare separată şi reciclare a diferitor fluxuri de deșeuri şi a deșeurilor de produse supuse reglementărilor de responsabilitate extinsă a producătorului; c) ține evidența și efectuează inventarieri la agenți economici, instituții şi organizații privind formarea, valorificarea şi eliminarea deșeurilor, precum şi stocurile de deșeuri păstrate;

d) suspendă, total sau parțial, potrivit procedurii prevăzute de Legea nr. 131/2012 privind controlul de stat asupra activității de întreprinzător, activitatea agenților economici în caz de depistare a încălcărilor foarte grave ale reglementărilor privind gestionarea deșeurilor, dacă acestea pot conduce la poluarea mediului;

e) constată şi examinează contravenții şi aplică sancțiuni conform Codului contravențional al Republicii Moldova nr. 218-XVI din 24 octombrie 2008 şi înaintează acțiuni pentru recuperarea prejudiciului cauzat mediului ca urmare a încălcării prevederilor actelor legislative şi normative în cadrul desfășurării activității.

De asemenea, în temeiul noii legi privind deșeurile, cu atribuții clare sunt învestite și autoritățile administrației publice locale.

Așadar, în vederea implementării legislației în domeniul gestionării deșeurilor, autoritățile administraţiei publice locale, în limita resurselor financiare aprobate în acest scop de către consiliul local pe anul bugetar respectiv, realizează următoarele activități:

a) crearea unui sistem eficient de colectare, de asigurare etapizată a condiţiilor pentru colectare separată și de transportare a deșeurilor și stabilirea modului de funcționare a acestuia, în conformitate cu prevederile prezentei legi și ale altor acte normative;

b) alocarea terenurilor necesare pentru colectarea separată a deșeurilor, inclusiv pentru colectarea deșeurilor de produse supuse reglementărilor de responsabilitate extinsă a producătorului, dotarea acestora cu containere specifice tipurilor de deșeuri, precum şi funcționalitatea acestora;

d) amenajarea unor spaţii speciale pentru depozitarea deșeurilor colectate separat, di- 
mensionate corespunzător, pentru a asigura protecția mediului și a sănătății populației;

e) depozitarea deșeurilor municipale doar în locurile special amenajate în corespundere cu documentația de urbanism;

g) evidența datelor şi informațiilor privind deșeurile şi gestionarea deșeurilor municipale colectate de la populație, de la unitățile comerciale şi instituții, în bază de contract, raportând anual aceste date, prin intermediul operatorilor de gestionare a deșeurilor municipale, Ministerul Agriculturii, Dezvoltării Regionale și Mediului în conformitate cu metodologia de ținere a evidenței şi de transmitere a informației, aprobată de Guvern.

De asemenea, autoritățile administrației publicelocalecontribuie,înlimitelecompetențelor stabilite de prezenta lege, la stabilirea unui sistem de management integrat al deșeurilor la nivel regional şi asigură cooperarea regională în vederea constituirii asociațiilor regionale de management al deșeurilor.

După cum menționam la început, o noutate în domeniul reglementării regimului deșeurilor este instituția responsabilității extinse a producătorului bazată pe conceptul european al economiei circulare, unde producătorul are obligația de a urmări întregul ciclu de viață a produsului, determinând întoarcerea produsului său la el sub formă de deșeu.

In acest sens, potrivit art. 12 din Legea nr. 209/2016 pentru a consolida reutilizarea şi prevenirea, reciclarea şi alte tipuri de valorificare a deșeurilor, persoanele fizice sau juridice (producătorul produsului) care, la nivel profesional, proiectează, produc, prelucrează, tratează, vând şi/sau importă produsele menţionate la alin. (14) sunt supuse regimului de responsabilitate extinsă a producătorului.

Responsabilitatea extinsă a producătorului reprezintă totalitatea de obligații impuse producătorilor, fie individual, fie colectiv, pentru recuperarea și valorificarea sau reciclarea produselor scoase din uz. Activitățile pentru aplicarea responsabilității extinse a producătoru- lui vizează măsurile de acceptare a produselor returnate şi a deșeurilor care rămân după utilizarea respectivelor produse, precum şi gestionarea ulterioară a deșeurilor şi asigurarea financiară pentru aceste activități.

Activitățilepentruaplicarea responsabilității extinse a producătorului trebuie să fie însoțite de măsurile necesare pentru a încuraja atât proiectarea ecologică şi producerea de produse, cât şi utilizarea componentelor şi materialelor care au un impact redus asupra mediului şi care generează o cantitate scăzută de deșeuri în timpul producerii şi al utilizării ulterioare, precum şi pentru a se asigura că valorificarea şi eliminarea produselor care au devenit deșeuri se realizează în conformitate cu respectarea prevederilor art. 3 şi 4. Prezența substanţelor periculoase în produsele menționate la alin. (14), supuse în mod prioritar reglementărilor de responsabilitate extinsă a producătorului, precum mercurul, cadmiul, plumbul, cromul hexavalent, bifenilii polibromuraţi, eterii de difenil polibromuraţi și substanțele ce distrug stratul de ozon, inclusiv hidroclorofluorocarburile, este reglementată prin prezenta lege şi prin actele normative privind gestionarea acestor produse, aprobate de Guvern. Măsurile menționate trebuie să încurajeze dezvoltarea, producerea şi comercializarea produselor cu utilizări multiple, care sunt durabile din punct de vedere tehnic şi care pot, după ce au devenit deșeuri, să facă obiectul unei valorificări sigure şi al unei eliminări ce nu poluează mediul.

De asemenea, o noutate pentru reglementarea regimului deșeurilor o constituie și sistemul informațional automatizat „Managementul deșeurilor". Astfel, în temeiul legii nr. 209/2016, art. 33, unităţile şi întreprinderile ce sunt antrenate în activitățile de gestionare a deșeurilor, inclusiv producătorii de deșeuri, participă la procesul de raportare a datelor şi informațiilor despre deșeuri şi gestionarea acestora conform cerințelor stipulate în lege şi prevederilor conceptului Sistemului 
Informaţional Automatizat „Managementul Deșeurilor" (SIA MD), aprobat de Guvern. SIA MD reprezintă totalitatea produselor de program şi a echipamentelor tehnice destinate colectării, stocării și procesării informației, formând resursa informațională Registrul „Managementul deșeurilor”, care va include evenimentele legate de circuitul economic al acestora, documentele care însoțesc acest circuit, inclusiv exportul și importul de deșeuri, producătorii de deșeuri și agenții economici autorizaţi pentru a activa în acest domeniu, precum și automatizarea business-proceselor subiecților circuitului deșeurilor și furnizarea informațiilor privind circuitul deșeurilor către autoritățile publice, persoanele fizice și juridice prin intermediul portalului departamental.

Informația privind realizarea măsurilor ce țin de aplicarea responsabilității extinse a producătorului pentru produsele menționate la art. 12 și datele privind cantitatea de produse puse la dispoziție pe piaţă, specificată în tone şi număr de unităti, precum și informația privind cantitatea, numărul și categoriile deșeurilor colectate şi tratate fac parte din SIA MD.

\section{Concluzii}

Din analiza conținutului noii legi privind deșeurile, constatăm că aceasta vine să aducă în concordanță prevederile legislației noastre cu cea a Uniunii Europene pe segmentul gestionării deșeurilor, acestea având la bază con- ceptul economiei circulare care cu mult timp în urmă și-a arătat eficiența la nivel internațional. $\mathrm{Cu}$ toate aceste, mai avem multe rezerve la capitolul implementare, dar și a dezvoltării legislației conexe domeniului gestionării deșeurilor, precum și a legislației de mediu, în ansamblu, ce ar strădui să reducă cantitatea deșeurilor, iar cele existente să fie prelucrate și reutilizate cât de mult posibil fără efecte negative asupra mediului, iar în consecință, asupra sănătății și calității vieții omului.

\section{Referințe bibliografice}

1. Constitutia Republicii Moldova din 29.07.1994. În: Monitorul Oficial al Republicii Moldova, 18.08.1994, nr. 1 .

2. Legea privind protecția mediului înconjurător Nr. 1515din 16.06.1993. În: Monitorul Parlamentului Nr. 10 din 01.10.1993.

3. Legea privind deșeurile, nr. 209 din 2907-2016. În: Monitorul Oficial Nr. 459-471 din 23-12-2016.

4. Legea nr. 1347 din 09.10.1997 privind deșeurile de producție şi menajere. În: Monitorul Oficial nr. 16-17 din 05.03.1998. Abrogată.

5. Strategia națională de gestionare a deșeurilor în RM, 2013-2027, Chișinău 2013.

6. Minea Elena-Maria. Protecția mediului. ClujNapoca 2010.

7. Suciu G., Prida T. F. Todor. Strategia de gestionare integrată a deșeurilor urbane solide la nivelul județului Cluj. Revista "GeTraDe" nr. 1/2006. Casa Cărții de Știință, Cluj-Napoca, 2006.

8. Trofimov I., Ardelean G., Crețu A. Dreptul mediului. Ed. Bons Offices Chișinău, 2015. 